\title{
The Effect of 3-Point 5-Post Shooting Drills Training on the 3-Point Shooting Success in Basketball Player
}

\author{
Taufik Hidayat, Tri Irianto, Sunarno Basuki \\ Department of Sport and Health Education \\ Universitas Lambung Mangkurat \\ Banjarmasin, Indonesia \\ bauntungbatuah86@gmail.com
}

\begin{abstract}
The basketball player of Junior High School 1 Banjarbaru has a 3-point shooting capability, which is still low. This study aims to determine the effect of 3-point 5-post shooting drills training on the success of 3-point shooting in basketball players of Junior High School 1 Banjarbaru. The research method used is pre-experiment design, with data collection techniques carried out through initial tests, providing treatment as many as $\mathbf{2 4}$ meetings and final tests. The population in this study was students who took basketball extracurricular at Junior High School 1 Banjarbaru, totaling 30 people. Meanwhile, the sample of this study was 20 people with a purposive sampling technique. The results showed that the initial test data on the success of 3-point shooting obtained an average $=2.70$ with a standard deviation $=1.418$. In the final test data, the success of 3-point shooting obtained an average $=\mathbf{6 . 0 0}$ with a standard deviation $=1.747$. The analysis results obtained t-count $=15.983>t$-table $=2.201$, with Sig. $(2$-tailed $)=0,000$. It turns out that Sig. (2-tailed) $<0.05$, thus the t-count is significant. In summary, there is an effect of a 3-point shooting drills 3-point training on the success of 3-point shooting for basketball players of Junior High School 1 Banjarbaru.
\end{abstract}

Keywords: training, 3-point 5-post shooting drills, 3-point shooting, basketball

\section{INTRODUCTION}

Basketball is a team sport; each team consisting of five players and aims to put the ball into the opponent's basket as much as possible and hold the opponent entering the ball. The basketball game is played by bouncing the ball to the floor to avoid opponents (dribble), passing the ball to the other teammates (passing), and then firing the ball toward the basket (shooting) to get the numbers done for four quarters. Each quarter has a duration of 10 minutes.

Playing basketball requires players who have good physical, technical, tactic, and mental strength. During the $4 \times 10$ minutes of playing, the player is required to be able to concentrate quickly, making decisions to obtain victory. The mastery of basic techniques supports playing basketball effectively and efficiently. It is done by practicing continuously. Practicing the basic techniques of playing basketball aims to make the player move effectively, efficiently, and avoid injury. According to Reference [1], basic skills in basketball are, namely: (a) handling the ball, (b) passing the ball, (c) dribbling, (d) shooting, (e) securing the ball from enemies, (f) jumping.

Shooting is one of the basic techniques of playing basketball that must be mastered. Shooting is a technique in basketball that directs or throws the ball toward the opponent's basket to get a number. Through shooting, the team will be more effective and efficient in playing, because the technique of shooting saves in energy that is used by shooting from any direction, and efficient in collecting numbers. In a basketball game, the opportunity to shoot to get very few points, this can be seen from the statistics of the match. Shooting becomes the choice to get a number, but in a match, few players choose to shoot either a 2-figure shot (medium shoot) or a 3-point shot (3-point shooting). If the players do a 3-digit shot, it is certainly a bit difficult to enter the ball, because of the distance away from the basket. However, when a player shoots two numbers (medium shoot), the possibility of the ball going into the basket is greater.

The difficulty of 3-point shooting is the distance from where to shoot with the basketball hoop. However, compared to shooting closer to the ring, it will be more effective, efficient, and easy to get three points without being interrupted by the opponent. The success of shots in a basketball game can be divided into three, namely shots that produce 1,2 , and 3 numbers. A player obtains one number when he puts the ball in the basket from a free throw shot, two numbers or called medium shoots when the player shoots in from the 3-digit line, and three numbers or 3-point shooting when the player shoots outside the 3-digit line. With several different types of shots, 3 -point shooting has a difficulty level to make a shot, because it has too much distance with the ring, a lot of angles or shooting points in the 3-point shooting area, and it is easy to do a trial shot during a match. During the match, many players can do the 3-point shooting. 3-point shooting is decidedly advantageous if appropriately used because with the distance that is too far away from the ring compared to 2-digit shots or 1 number that is always blocked by opponents, the success of 3 -point shooting to get very high numbers. However, what happens on the field, even though many players try to shoot one or two numbers, many players fail when doing so because opponents always block them, this requires a coach's breakthrough for the success of 3-point shooting that produces three points and opponents rarely guard it. 3-point shooting is the shot that produces the highest point in a basketball game.

Statistics in the NBL (National Basketball League) 2012 season only a few players who use 3-point shooting, only two players who made 22 attempts of 3 -point shooting with ten shots entered [2], while the highest percentage of teams for 3point shooting is $39 \%$ of the balls entering the test shots [2].

Statistical data at the 2016 IBL Final CLS Knights Surabaya vs. Pelita Jaya EMP Jakarta shows only a few players use 3-point shooting. At CLS Knights Surabaya, there were only four players perform 183 -point shooting attempts with ten shots were shot, which do not enter eight attempts of 3 -point shooting, while the players who used 2-point shooting 
there were ten players who conducted 32 attempts of 2-point shooting with 12 shots entered, who did not enter 20 times the 2-point shooting attempt.

Based on observations made at the junior high school level basketball game in Junior High Schooll Banjarbaru, the statistics of the match between Junior High School 1 Banjarbaru vs. Junior High School 5 Banjarbaru, there are only a few players, used 3-point shooting. Meanwhile, at Junior High School 1 Banjarbaru, only three players performed eleven 3-point shooting trials with three shots, which did not enter eight attempts of 3-point shooting. At the same time, players who used a 2-point shooting, ten players, carried out 25 attempts of 2-point shooting with ten shots entered, who did not enter 15 times the 2-point shooting attempt (basketball match for Banjarbaru 1 Public Middle School Anniversary 2016). In general, players rely on 2-digit shooting, and rarely do 3-point shooting trials, even though it is very profitable to win the game, the more balls entered with 3 -point shooting, the better than their opponents. There is still a lack of training specifically to practice 3-point shooting to find out the success of 3-point shooting, so the ability of 3point shooting is still lacking or rarely enter when conducting 3 -point shooting trials during a match. Besides, many trainers think that 3-point shooting practice is not important and is often given when approaching competition, not given regularly to practice shooting. Based on the experience of training the basketball team of Junior High Schooll Banjarbaru and the results of observations on the male athletes of the basketball teams of Banjarbaru City and South Kalimantan, there are still many athletes who prefer 2-point shooting over the 3-point shooting. Therefore, in this study, the researcher tried to apply the 5-spot shooting drills in practicing the shot to improve the success of a 3-point shooting on the basketball player of Junior High School 1 Banjarbaru. Based on the background stated above, this study is entitled "The effect of 3-point shooting drills 3-point training on the success of 3-point shooting in basketball players of Junior High School 1 Banjarbaru

\section{METHOD}

This research employed a pre-experimental design [3]. It is said pre-experiment design because the design of this study is not yet a real experiment, or there are still external variables that influence the formation of the dependent variable. Hence, the experimental results which are dependent variables are not solely influenced by the independent variables. It can happen because there are not any control variables, and the sample is not chosen randomly. The design in this study was the OneGroup Pretest-Post Design.

\section{RESUlTS AND DisCUSSION}

The initial test results of the 3-point shooting success of basketball on Banjarbaru Junior High School 1 basketball players received an average of 2.70 , a standard deviation of 1.418. From the results of this test, the highest score is 5 and the lowest score is 1 . After being treated 3-point training 5post shooting drill, there is a significant increase in the results of 3-point shooting basketball success. It is evidenced by the final test results of their 3-point shooting success with an average of 6.00, the highest score 9, and the lowest score 3 .

Based on the observations of the researcher and the results of the initial test success of 3-point shooting on the basketball player of Junior High School 1 Banjarbaru, the results of the success of a 3-point shooting on the basketball player of Junior High School 1 Banjarbaru are still not maximum. In the initial test, the players are asked to do 3-point shooting success at three points, and they were given 30 seconds at each point. It turned out that the results of their 3-point shooting success were inaccurate; even many were not on the ring. Based on the observations of the researcher, this is caused by the lack of training in the success of a 3-point shooting in the basketball player of Junior High School 1 Banjarbaru. Therefore, the researcher provided treatment of 3-point 5-post shooting drill exercises.

In this study, the researcher provided treatment to increase the success of 3-point shooting with a 3-point 5-post shooting drill's exercises that are modified according to the principles of training. After being given treatment three times a week for eight weeks starting on September 17 - November 9, 2018, with the final test success of 3-point shooting on November 11,2018 , the results of data analysis showed a significant increase in the results of the success of 3-point shooting players basketball Junior High School Banjarbaru. The final test data of 3-point shooting basketball success shows an average of 6.00 , which is higher than the initial test data of 3point shooting basketball success that is only $=2.70$. In the initial test, the highest score $=5$ and the lowest score $=1$, while in the final test, the highest score $=9$ and the lowest score $=3$.

The results of the treatment of the 3-point 5-post shooting drills exercise showed that the shooting ability of the Junior High School1 Banjarbaru players improved, as evidenced by the final test results of the success of 3-point shooting at three points. Thus it can be proven that the 3 -point 5-post shooting drills practice can improve the 3-point shooting results of the basketball players of Junior High School1 Banjarbaru.

The improvement in the results of the success of 3-point shooting for basketball players of Junior High School 1 Banjarbaru is a result of providing treatment with exercises that lead to the progress of basketball players in improving the ability to perform 3-point shooting success. Through 3-point practice, the 5-post shooting drills will become trained or become an automation motion so that in the competition, there will be no hesitation in making 3-point shooting success, which helps to get many points with the final result of the victory.

For the results of the 3-point 5-post shooting drills to be maximal, the intensity of the exercise must be considered. To find out the ideal intensity used in training, coaches must regularly test athletes to find out their maximum capacity to carry out a given exercise. In this study, the athletes were given an initial test so that they could know the maximum strength of the athletes. According to reference [4] states that: the most important skill in basketball is the ability to shoot balls into the basket. According to Reference [5], a coach must master the principles of training. According to Reference [6], biomotor is the ability of human motion, which is influenced by the condition of internal organ systems. Based on several theories above that a person's skills are needed in shooting a basketball, of course, with routine practice.

In this study reinforced by reference [7], the results showed that there was a significant difference between before and after the 3-point shooting drills training was given to the 3 -point shooting results.

\section{CONCLUSION}

The conclusion of this study is based on data analysis, hypothesis testing, and the discussion done in the previous chapter, that there is a positive and significant effect of $0,000<$ 
[3] Sugiyono, Metode Penelitian Kombinasi (Mixed Methods), Bandung:

0.05 3-point 5-post shooting drills training on the success of 3-point shooting in basketball players of Junior High School 1 Banjarbaru.

\section{ACKNOWLEDGMENT}

We would like to thank the Dean of the Faculty of Teacher Training and Education, Universitas Lambung Mangkurat, who has supported the researcher in the form of funding. Therefore, we could join this International Conference.

\section{REFERENCES}

[1] V. Amber, Petunjuk Untuk Pelatih \& Pemain Bola Basket, Bandung: Pionir Jaya, 2008.

[2] Team Statistics, "Speedy NBL Indonesia Preseason Tournament," nblindonesia.com, 2012.
[4] D. Kosasih, Fundamental Basketball A First Step to Success, Semarang: CV. Elwas Offset, 2008.

[5] Mansur, Materi Pelatihan Pelatih Fisik Level II. Jakarta: Asdep Pengembangan Tenaga dan Pembina Keolahragaan Deputi Bidang Peningkatan Prestasi dan Iptek Olahraga Kementerian Pemuda dan Olahraga Republik Indonesia, 2009.

[6] Sukadiyanto, Pengantar Teori dan Metodologi Melatih Fisik. Bandung: Lubuk Agung, 2011.

[7] M. D. Fikri "Pengaruh Pelatihan 3-Point 5-Post Shooting Drill's Terhadap Hasil 3-Point Shooting Club Bola Basket Putra SMA Negeri 1 Taman Sidoarjo,”e-Journal Unesa, 2013. 